\title{
Exploration of transnationalism as a concept and phenomenon in Public Administration \\ BR HANYANE
}

\begin{abstract}
Transnationalism as both a phenomenon and a concept has received negligible attention in modern times in relation to the practice of public administration and its corresponding field of study. This article provides an account of the meaning and the relevance of both the concept and phenomenon as received and applied by practitioners and scholars in the said practice and field of study. From the latter, a deliberate approach towards policy matters is undertaken in relation to the concept and phenomenon of transnationalism. In this article policies used by the national Department of Home Affairs in South Africa form the basis from which a case is made relevant to this topic in $\mathrm{p}(\mathrm{P})$ ublic a(A)dministration. Additionally, case studies in the SADC region are considered. This article therefore argues that transnationalism is as much local as global issues such as immigration, citizenship, global economy, service delivery, government (in)efficiency and (in)effectiveness and such other matters of public interest.
\end{abstract}

Keywords: transnationalism, migration, public administration, human mobility, citizenship, cross-border

\section{Introduction}

Since the 9/11 bombing in New York, global mobility has been restricted to local boundaries. Entry into countries in the Western world has become controlled by suspicion and "home designed" laws of restriction that discourage immigration and asylum seeking movement. The nation-state has thus begun to re-invent itself in the preservation of autonomy and power. Transnationalism has also begun to be seen as a driving force in shaping global politics, labour and social movements. As a result, this phenomenon seems to supersede localism and/or the existence and preservation of the nation-state. Conversely, "political risk management" has also become a priority function of legislatures in most democratic countries in defence of democracy, patriotism and nationalism. This observation, however, does not mean that all is well. Internal problems such as xenophobia continue to increase unabated.

In re-inventing the nation-state, governments of most countries in the developing world have expressed interest in establishing and modifying economic, political and social growth and

1 Department of Public Administration \& Governance, North West University, Private Bag X6001, Potchefstroom, 2520, South Africa, barry.hanyane@nwu.ac.za 
development goals. Reference is made in this instance to the southern African region. Apparently, the most pressing issue faced by modern governments is to promote and maintain prosperity, development and economic growth. Approaches and theories of development and dependency best describe the theoretical underpinnings of this debate. These theories are used in analysing the rate of development in underdeveloped countries, especially in Africa. African countries, South Africa included, have started to embrace and implement programmes such as the New Partnership for Africa's Development (NEPAD) (Mulaudzi, 2009: 54). Critics of this programme have, for instance, labelled it an ambitious plan aimed at achieving more at the expense of limited resources.

The question that stands out is how nation-states can start to promote freedom of movement of individuals in a given regional geographical area. Proponents of globalism (Stiglitz, 2001: xvii) have also added a dimension to the whole debate on the phenomenon of transnationalism, albeit at a different level. In this article, the phenomenon and concept of transnationalism is equated with the process of human movement from their country of birth to a host country of choice. Inevitably, this phenomenon has to be defined in the context of its appeal, relevance and significance of a particular context. The question to be asked is whether transnationalism as both a concept and a phenomenon has a place in a political and public domain within a given society where citizens of the world are seen as subjects.

This article will attempt to illuminate the complexities of transnationalism as both a concept and a phenomenon. Firstly, a definition of the concept transnationalism will be made for theoretical purposes. Secondly, the phenomenon of transnationalism will be contextualised in an environment where a person is seen as a worker without boundaries and restrictions based on geographical settings. Key variables are identified that shape the content and nature of the concept and phenomenon. The following variables or factors are discussed: the definition of transnationalism, transnationalism as a phenomenon in the southern African context, implications of transnationalism for South Africa and selected neighbouring countries of the south, and recent incidents on the negative consequences of transnationalism.

\section{Contextualising transnational research in Public Administration and Management}

When does a research area or topic become relevant to a discipline? Can a topic in the area of civic interest or public interest as it is known in certain areas be considered researchable in Public Administration and Management (PAM)? What happens when some members of the department linked to the afore-mentioned discipline's research committee reject it outright? A few years later, now a colleague of ours, Valiant Clapper (2000), in his PhD thesis wrote about the subject, albeit in its limited usage as a concept in his study titled "Organisational culture and transformation: the role of the Department of Public Service and Administration". Speaking of the South African public service, it should be noted that the Department of Home Affairs, for instance, has two components, namely civil and immigration administrative components. It is the immigration component that has some form of relations with the topic on transnationalism. Immigration deals with movement of people from one area to another. Transnationalism focuses on social and economic spaces created by migrant workers who retain some measure of connection to their original country of birth.

In her inaugural lecture at the University of Johannesburg on 12 September 2007, Christelle Auriacombe presented a topic titled "Public governance and the public interest: Speaking truth to power". Critical issues pertinent to the usage and importance of the conceptual 
argument on public governance and public interest were highlighted. This presentation indicated that the said conceptual argument is alive and well in the discipline, despite earlier suggestions of its reception by the members of the research committee in the said department. The question is then asked: when is a topic considered a researchable topic? Is it because of its popularity, or the reception shown by those who we regard as custodians of research agenda? Think of a restaurant that insists on serving what patrons do not want to eat. Why bother to be a patron then? Think of a restaurant menu that serves "Thai prawn wraps" with a steamy sauce and the option of frog legs as a starter. Instead of opting for a beef fillet, why not order a kudu fillet served with an option of rice or baked potato? To cut the matter short, we in the discipline of PAM have forsaken our passion, focus and statement of intent in critical areas such as those captured in the following questions: where should the discipline focus its research attention? Which areas are distinctively PAM research areas?

A number of research articles have been produced by scholars in PAM on areas such as migratory tendencies and related policy issues. It is the researcher's opinion that the topic on transnationalism, beyond issues of migration and immigration researched by scholars and practitioners of PAM, warrants attention. Sub-themes such as transnational human rights (equivalent to research areas of social justice and constitutionalism), transnational migration (equivalent to research areas of migratory policy and public administration) and transnational communities (equivalent to research areas of transnational service delivery, transnational informal economy and feminist theory (Briggs, McComark \& Way, 2008: 637-638) social security, transnational and migratory careers and welfare) require the attention of PAM practitioners and academics. In recent times, the feminist theory of analysis of transnational realities has emerged (Briggs et al., 2008: 637). In the feminist theoretical domain, the variable of gender is used equivalently to variables of politics, society and culture related to transnationalism. With reference to society and culture as symbols of gender or feminist studies, transnational transactions are influenced by cultural symbols, meaning of such symbols, social institutional arrangements and subjective identity such as gender. For example, the proliferation of hair salons owned and managed by African migrants in South Africa post-1994 is seen as an expression of feminist tradition of "ownership". This article will consider the meaning of the concept of transnationalism, which is crucial to the argument presented.

\section{Meaning of transnationalism}

Transnationalism is a social movement grown out of the heightened interconnectivity between people and the loosening of boundaries between countries (Harney \& Baldassar, 2007: 190). This means that the concept of transnationalism embraces processes and patterns connecting people, businesses and other entities in different places of the world. Additionally, it denotes economic meaning involving the global re-organisation of the production process. In this instance, various stages of production can occur in different countries with the aim of reducing costs. Take the example of popular efficient Western companies such as Harman International Pty Ltd which specialises in the production of audio components worldwide. Designs are made in the United Kingdom and the production of the final product takes place in China. South African perceptions about "everything and anything made in China" are quite diverse and imbued with scepticism, prompting everyday utterances such as "fake" with reference to poor quality of products produced.

Transnationalism as a process also has economic underpinnings. Popularly known as Globalisation (Castles, 2007: 352-353), which became prominent in the latter half of the $20^{\text {th }}$ 
century, transnationalism has had an impact in the establishment of Multinational Corporations that seek to promote efficient means of economic production, irrespective of political boundaries (Mulaudzi, 2009: 50-51) and gender affiliation (Briggs et al., 2008: 638). But from a social perspective, transnationalism refers to the flow of people, ideas and goods between regions. As a result, there seem to be an increasing flow of migratory work force, globalised corporations (Clavin, 2005: 439), global money flow and global scientific cooperation, establishing links between people, institutions or nation-states (Metropolis, 2007: 1-2). Such institutions may either be public or private in a given nation-state.

Transnationalism beyond mere migratory behavioural patterns takes the form of ongoing movement between two or more social spaces. Facilitated by increased global transportation and telecommunication technologies, more and more migrants have developed strong transnational ties to more than one home country. Transnationalism also refers to global cooperation between people and points to activities which transcends national boundaries, wherein nation-states governments do not play the most important or even significant role. In this instance, the concept and phenomenon of regionalism takes shape (Mulaudzi, 2009: 51-55). Furthermore, transnationalism often entails a vision of the obliteration of nationstates to make way for a unified world government. The recent drive in Europe to establish the European Union towards one common economic, political, cultural and financial market domain serves as reference. Apparently, transnationalism is closely related to cosmopolitanism, where the former describes the individual experience, and the latter is the philosophy behind it.

\section{Transnationalism as a phenomenon in the southern African context}

To some degree, the African continent is still viewed by outsiders as ungovernable, misunderstood and a place of mysteries unresolved. Lack of documented evidence as to the level and degree of movement among labourers implies that the phenomenon is either nonexistent or misrepresenting of the realities on the ground. This is also compounded by forced movement of people in war-torn African countries and those countries ravaged by internal strife as well as the lack of basic services and public goods. Social problems such as poverty, hunger and natural disasters have also contributed to the involuntary movement of people in Africa. As yet, there needs to be a scientific investigation to determine the extent of movement of professional migrant workers from one African country to another. Common movement of this nature has been the uncorroborated survey of professionals from Africa to Europe, Oceania and the Western world. From Egypt to South Africa, professional workers in the fields of medicine, telecommunication and natural sciences have left their countries of origin in search of "greener pastures". This has resulted in what is popularly known as "brain drain", and not necessarily from an individual perspective of seeking a better life elsewhere.

As already alluded to, reliable scientific evidence is yet to be collected, analysed and published suggesting the degree or magnitude of this dysfunctional situation. South Africa is one of the many African states that have lost professional workers to the economic benefit of other wellto-do countries. Countries such as the United Kingdom, United States of America and some in Europe have so far benefited. In the field of public administration for instance, one has yet to determine how many public service professionals actually trade their skills and expertise within the South African government arena. What impact, if any, does this phenomenon have for the South African economy and the drive to improve efficient and effective delivery of public goods and services? In 2007, in a statement reported in the media circles, the then Minister of Public Administration, Mrs Geraldine Fraser-Moleketi, was quoted as saying 
that the South African government intended to hire senior government workers from India, Africa and Oceania to serve in the public service ranks. Reasons cited were inter alia, lack of capacity to deliver public services and goods, lack of professionalism in the public service generally, lack of necessary skills for the public service and the need to strengthen the South African public service staff compliment.

Notably, some of the private sector industry have unilaterally promoted the idea of seeking foreign African work force to trade their labour in exchange for cheaper wages. Cape Town`s hospitality industry serves as reference in this regard. The situation in Zimbabwe has somehow contributed in the distortion of the actual meaning and manifestation of the phenomenon of transnationalism. Due to sociopolitical conditions in that country, desperate highly skilled workers are forced to leave Zimbabwe for South Africa, searching for economic opportunities and benefits (Gaidzanwa, 1999; Solomon, 2003; Muzvidziwa, 2005; Duri, 2010). In the process, some skilled workers open themselves to abuse and poor living conditions, arranged by shady "organisers" for social and economic exploitation, while other skilled workers receive better working contracts and conditions. Interestingly, Yawlui (2013: 12) identified the movement of skilled labour into the South African job market (public and private sectors) as a contributing factor for the sporadic increase in xenophobic cases. Instead, professional migrant workers from Namibia, Swaziland, Uganda, Tanzania, Kenya, Nigeria and Malawi have voluntarily sought for economic opportunities in South Africa. Migrant workers from the Democratic Republic of Congo (DRC), Zimbabwe, at some stage Sierra Leone, and other countries, have been forced to seek job opportunities in South Africa, Europe and the Western countries. Research in this area is needed to determine and measure the extent of this problem. Of particular interest is the degree to which this situation impacts on the efficiency of public administration in South Africa.

This article proposes that possible topics and/or concerns that require immediate attention by public administration thinkers and practitioners are, inter alia:

- $90 \%$ of post-graduate research in Public Administration and Management is focused on "local problems". This serves as the researcher`s own observation as a member of the Senior Degrees Committee in the afore-mentioned department at the University of South Africa's Pretoria campus.

- From a pragmatic point of view, this phenomenon is "new" to South Africa. It appeals at the individual level, rather the collective (society) scale. Therefore, one cannot say that transnationalism is not people-centered.

- Given South Africa`s recent history, most citizens have not come to terms with sharing the "Africaness" with legal and/or illegal persons, especially from other African countries, post-apartheid period.

- There is a need to redefine and perhaps contextualise understanding of sociocultural and, sometimes, sociopolitical philosophies such as "Ubuntu" within the context of harmonising social, political, economic, cultural and even religious meanings of the world.

- Public Administration (and Management) has a profound role to play. In this instance the discipline has to make a meaningful contribution in determining the following:

- What determines the international scope of this investigation or inquiry?

- Can public policy-making, for instance, exert some form of influence in matters related to transnationalism? 
- Can intergovernmental relations also exert some form of influence in matters related to transnationalism?

Beyond the scope detailed above, further questions on the topic of transnationalism and the concomitant government response require immediate attention. Proposed issues are, yet not limited to:

- Realities of extreme social phenomenon such as xenophobia that have an impact on the management of transnationalism in the southern African region (Zondi, 2008: 26-35).

- Risk management (administratively and politically) - poverty, political instability, lack of effective government structures and systems, diseases, poor living standards and other factors.

- Social and economic insecurities related to global economic meltdown/credit crunch or recession.

- Globalisation - its negative impact on transformationalism (Castles, 2007: 352-353).

- Vulnerability - rights and ownership.

- The rise of China and India in challenging the US hegemony as a superpower and, more recently, the G4 countries/alliance of Russia, Brazil, India and Malaysia.

- Globalising metropolitanism - reflective of rapid urbanisation in nation-states.

Other factors considered in this article as pull and push, respectively, warrant discussion.

\section{Pull factors in promoting transnationalism}

According to Sirkeci (2009: 5), transnationalism is realised when certain factors are considered. At the helm of this debate, human insecurity is a prime determining factor. Sirkeci (2009: 5) refers to Maslow`s (1943) five-stage hierarchy of needs model to justify the importance of human needs as pull factors in promoting transnationalism. Specifically, Sirkeci (2009) emphasises the relevance of the second tier of the hierarchy of needs, referred to as "security and safety". Conversely, human insecurity can be seen as a concept defining various situations where conflicts lead to perception of deprivation of some kind, among certain people, in a given context. These contexts could range from the civil strife for Arab countries in North Africa and the Middle East or environmental hazards for countries in the Asian pacific such as New Zealand, Indonesia, Thailand and other countries, which are perceived subjectively by individuals, households, communities and public policymakers. Human insecurity is relative, subjective and may arise from civil conflicts, wars, latent tensions and/or environmental catastrophes. Perception of human insecurity can be based on material or non-material environments. For example, members of a minority group may feel insecure because they are not allowed to practice their own cultural traditions and develop their own mother tongue. This was felt by some Afrikaans-speaking people in South Africa after 1994 when South Africa became a democratic state. Therefore, the main motive in observing international migration can be interpreted as seeking human security-or avoiding human insecurity.

Another pull factor in realising transnationalism is conflict. Conflict in transnationalism is associated in this article with revolts, wars, armed conflict, contests, competitions, disputes and tensions. As Sirkeci (2009: 8) puts it, conflicts and migrations that are constantly transformed by transnational space. In this instance, the dynamic nature of conflict and migration influences the structures, actors and processes. Subsequently, different channels of 
migration become available while others disappear. For instance, the observation of changing admission rules, visa policies, boarder control policies as well as new migration types have a profound effect on transnationalism. The recent South African case reference of granting skilled and semi-skilled workers from Zimbabwe during the period of 2010 to 2011, visa permits to seek temporary employment in South Africa is a case in mind. Here public officials and some executive office-bearers in the employ of the public service must see to it that there is proper effective structure, systems and processes conducive to achieve the stated goals. Latest developments in transnational research and studies point to the emerging discourse of migratory careerism, especially for public servants (Martiniello \& Rea, 2014: 1079-1085). For example, the South African public service may consider attracting best candidates from the diaspora to serve in strategic key public service positions. Opportunities, networks and migratory structures are established.

In transitional migration space, there are conflicts among individuals, ethnic or religious groups, social classes, supranational agencies and countries. As Mulaudzi (2009: 49) argues, migration and increased levels of informal cross-border trade are some of the defining features and indicators of the predominance of the new regionalism in southern Africa. Transnationalism is viewed in this article as a product of neo-liberal tendencies emanating from the globalisation debate. In this instance, governments are expected to spend less and to allow the private sector to lead in public and private investments. Thus, governments should spend money in areas of human development such as education and public health. As Mulaudzi (2009: 50) puts it, regional states especially in the SADC region, should make effort to create alliances and to pool resources with neighbours in order to effectively respond to the challenges posed by globalisation, putting the state at the centre of the regional integration agenda. The closure of Hyundai and Volvo plants in Botswana, owing to pressure from South Africa, illustrates this point.

According to Sirkeci (2009: 9), another pull factor for transnational conflict is gender security. Gender inequalities and traditional gender roles as well as unwanted female children are areas with potential for conflict. Another related area is the homosexuality and attitudes towards it in some countries of origin (for example, Uganda) and asylum seeking gays escaping from places such as Ethiopia and war-torn Somalia. Sirkeci (2009: 9) also notes the influence of environmental disasters as a source of conflict in managing transnational movements. People can be displaced in their original countries of birth, while some cross borders because they "can no longer gain a secure livelihood" in their homeland due to environmental problems. This may further cause conflict between communities and individuals over scarce resources such as water. Governments of countries affected by environmental problems must then work together to deal with potential environmental threats. A good example in southern Africa was the signing of the Great Limpopo Transfrontier Park agreement between heads of state of Mozambique, South Africa and Zimbabwe on 9 December 2002 (Rodgers, 2009: 1). This initiative was also aimed at curbing animal poaching. In addition to poaching, the Park authorities also had to deal with Mozambicans who were constantly crossing through the Park. According to Rodgers (2009: 402), Mozambicans regularly travelled from their rural villages to the industrial centres of South Africa in search of work from the mid-nineteenth century onwards. This practice continued into the twentieth century and was gradually institutionalised and controlled. In the decades before the 1980s, illegal migrants crossing the Park proved to be of some value to the Kruger National Park (KNP) section of the new Park. Faced with a high demand for cheap labour to build infrastructure of the Park, the warden, in his capacity as Justice of the 
Peace, sentenced trespassers (or "deurlopers" in the Afrikaans nomenclature of the KNP) who were arrested for two weeks of forced labour. Interestingly, once they had served their sentence, prisoners were permitted by KNP officials to proceed into South Africa and continue their search for work (Carruthers, 1995: 95).

The establishment of the Park was also aimed at achieving an ambitious goal of establishing one of the biggest conservation parks in the world, as attested in the Park's eventual expansion from $35000 \mathrm{~km}^{2}$ to $100000 \mathrm{~km}^{2}$, mostly into southern Mozambique. South Africa`s KNP and Mozambique`s Limpopo National Park (LNP) were the focus of integration. In August 2006 the Giriyondo border post was established and put into operation between South Africa and Mozambique. Later, the Lobito and Maputo Development Corridors were established (Mulaudzi, 2009: 49). The then president of South Africa, Thabo Mbeki, described the Park as the "beginning of a new era when we will bring down the colonial fences which divided our nations". Coincidentally on his $85^{\text {th }}$ birthday, Nelson Mandela gave his unequivocal support to the transfrontier initiative by saying: "I know of no political movement, no philosophy, no ideology, which does not agree with the Peace Parks concept, as we see it come into fruition today."

\section{Push factors in promoting transnationalism}

Factors such as lack of job opportunities, socioeconomic deprivation and wage differentials, protests against environmental degradation, and workplace closures can be conceptualised as sources of conflict, albeit non-violent one (Munck, 2010: 209; Sirkeci, 2009:10). Similarly, dual labour markets and ethnic discrimination in destination countries would also reflect a conflict between immigration labourers and natives. As Munck (2010: 209-214) argues, the demise of neo-liberalism and the resurgence of Marxist thinking in managing labour on a global scale led to the resuscitation of the Polanyi problematic. The role of the state, organised labour, social capital and the economy needed to be redefined in the wake of the 2007 global economy meltdown. New policies and thinking on economic affairs became a reality, refuting claims that there was no alternative to globalisation. Despite this reality, commodification of labour remained unabated; and, so was the movement of goods and services from one country to the other. Unfortunate incidences of xenophobia in South Africa as a case, are a reflection of the unintended consequences of transnational migration. Other countries in sub-Saharan region experience unique conditions that are different from those in South Africa. Two examples are discussed hereunder.

\section{Notable case studies of transnationalism in sub-Saharan Africa}

Sub-Saharan African countries such as Zimbabwe, Zambia, Botswana, Angola, Uganda and Tanzania experience transnational migration in ways that reflect realities such as displacement, because of internal strife, poor management of the economy, lack of employment opportunities and investments, inadequate educational opportunities and other associated challenges. According to Spaan \& van Moppes (2006: 3) migration policies of subSaharan African states have gradually evolved from laissez faire to more restrictive policies. These policies are generally based on politico-economic motives and, at times, ethnic and nationalistic considerations. The following table illustrates how few sub-Saharan African countries managed transnational migration in the past three decades. 
Table 1: Management of transnational migration by selected Southern African countries

\begin{tabular}{|c|c|c|c|}
\hline Country & Economy/labour & Policy & Type \\
\hline Kenya & $\begin{array}{l}\text { Labour-importing } \\
\text { and labour-exporting. }\end{array}$ & $\begin{array}{l}\text { Liberal labour. In } 2006 \\
\text { Kenya`s net migration } \\
\text { was estimated at } 0 \\
\text { migrants } 1 \text { r } 000 \\
\text { population (CIA, } 2006 \\
\text { estimates). }\end{array}$ & $\begin{array}{l}\text { Less restrictive absorbing labour } \\
\text { migrants mostly from Somalia, Sudan, } \\
\text { Ethiopia, Uganda and Rwanda }\end{array}$ \\
\hline Rwanda & Less solid & $\begin{array}{l}\text { Extreme liberal } \\
\text { characterised by political } \\
\text { instability }\end{array}$ & $\begin{array}{l}\text { Complex. Most Rwandans were hosted } \\
\text { by neighbouring countries such as } \\
\text { Tanzania during the genocidal } \\
\text { incidence in } 1994 \text {. }\end{array}$ \\
\hline Somalia & $\begin{array}{l}\text { Traditional labour } \\
\text { exporting country }\end{array}$ & $\begin{array}{l}\text { Ad hoc basis or non- } \\
\text { existent. }\end{array}$ & $\begin{array}{l}\text { Labour-donor country. Since } 1977 \\
\text { Somalia has been plunged into internal } \\
\text { strife, chaos, civil war and anarchy. } \\
\text { Kenya, Yemen, UK, Ethiopia, Djibouti, } \\
\text { and lately South Africa have benefited } \\
\text { from Somali labour. }\end{array}$ \\
\hline $\begin{array}{l}\text { South } \\
\text { Africa }\end{array}$ & $\begin{array}{l}\text { Highly regulated e.g. } \\
\text { Aliens Control Act of } \\
1991 \text { and several } \\
\text { bilateral agreements, } \\
\text { indigenisation, use of } \\
\text { labour brokers. }\end{array}$ & Highly regulated & $\begin{array}{l}\text { Benefited from labour-donor countries } \\
\text { such as Mozambique, Zimbabwe and } \\
\text { Lesotho, mostly in the mining and } \\
\text { agricultural sectors }\end{array}$ \\
\hline
\end{tabular}

Source: Adapted from Spaan \& van Moppes, 2006.

From the preceding analysis, managing migrant transnational movement in the sub-Saharan context has been a complex process. The southern African countries have also experienced their share of difficulties in areas of security and governance, and Manyange (2014: 84) points to migratory hostilities between Tanzania, Rwanda and Burundi in recent times. Such political hostilities and challenges have a negative impact on the region's public sector human development, the role of government in regulating labour movement, specifically for the public service, promoting formal economic activities and ensuring better livelihoods. This article advances the need to acknowledge the significance, where possible, of labour regulation by legitimate means as critical in managing transnational realities.

\section{Policy implications of transnationalism in South Africa}

According to Spaan \& Van Moppes (2006: 3-4), few sub-Saharan African countries implement an explicit and tightly controlled migration policy. In general, it can be said that the policies of sub-Saharan states have gradually evolved from laissez-faire to more restrictive policies. Evidently, migration policies vary according to country and period, but they are generally based on politico-economic motives and, at times, ethnic and nationalistic considerations. Sub-Saharan African countries often resorted to more restrictive policies during the 1970s, in the form of stricter boarder patrols, regulation of the internal labour markets through labour inspections and administrative measures such as the use of entry visa and work permits (Spaan \& van Moppes, 2006: 3). South Africa has over the past 15 years or so become a sanctuary for refugees from war-torn neighbouring countries like Somalia. 
The international position of South Africa as a regional player of note and its ability to influence political and economic trends in the global community cannot be ignored. From a local perspective, South Africa needed to establish a strong policy regime in dealing with issues relating to transnational migration and labour, for example.

Brennan (1984: 416) notes, South Africa is the only country on the sub-continent where labour migration has been highly regulated for several decades by means of official recruitment schemes. Some African countries initially pursued more liberal immigration policies, which were subsequently followed by forced expulsion of migrant labour, resulting from an economic downturn if not for political reasons. To this end, the following policies were established to regulate transnational mobility in South Africa (table 2). These policies seek to regulate internal affairs associated with the right to citizenship, regulating matters of immigration and migration of people in and out of the country, refugee services and registration of bona fide citizens.

Table 2: Policies administered by the National Department of Home Affairs

\begin{tabular}{|l|l|}
\hline Legislation & Focus/objective \\
\hline Immigration Act, 2002 (Act 13 of 2002) & $\begin{array}{l}\text { Empowers the Department of Home Affairs to } \\
\text { promote a human rights based culture in both the } \\
\text { government and civil society domains in relation to } \\
\text { immigration control. }\end{array}$ \\
\hline $\begin{array}{l}\text { Immigration Amendment Act, 2004 (Act 19 of } \\
\text { 2004) }\end{array}$ & $\begin{array}{l}\text { To amend certain sections of the Immigration Act, } \\
2002 \text { (Act 13 of 2002) }\end{array}$ \\
\hline Refugees Act, 1998 (Act 130 of 1998) & $\begin{array}{l}\text { Regulation of all matters pertaining to the } \\
\text { establishment of structures dealing with refugee } \\
\text { affairs including application for asylum, rights and } \\
\text { obligations of refugees. }\end{array}$ \\
\hline $\begin{array}{l}\text { South African Citizenship Act, 1995 (Act 88 of } \\
\text { 1995) }\end{array}$ & $\begin{array}{l}\text { Deals with all matters about citizenship, } \\
\text { naturalisation, citizenship by descent, loss of } \\
\text { citizenship, renunciation of citizenship, deprivation } \\
\text { of citizenship and other related matters. }\end{array}$ \\
\hline $\begin{array}{l}\text { South African Citizenship Amendment Act, 2004 } \\
\text { (Act 17 of 2004) }\end{array}$ & $\begin{array}{l}\text { Repeal section 9 of Act 88 (above) and the insertion } \\
\text { of section 26B in Act 88 of 1995 }\end{array}$ \\
\hline Identification Act, 1997 (Act 68 of 1997) & $\begin{array}{l}\text { Regulates the establishment and provisions of the } \\
\text { population register and related functional portfolios } \\
\text { and related functions. Furthermore, the Act } \\
\text { regulates functions such as the assignment of } \\
\text { identity documents (including ID numbers, } \\
\text { handling of applicants photos and fingerprints). } \\
\text { Chapter 2 of the Act outlines offences and penalties } \\
\text { associated with related functions }\end{array}$ \\
\hline
\end{tabular}

Source: Adapted from the Department of Home Affairs, 2007: 1-136.

\section{Conclusion}

This article has devoted attention to focus on transnationalism in the context of sub-Saharan Africa, taking into account developments in the discipline and practice of public administration and management. Practical realities in relation to the conceptual framework were emphasised. Specific case references to the conceptual argument and practice of transnationalism in sub-Saharan Africa was also given attention. The Kenyan, Somalian, Rwandan and South African case references were utilised. As a process and conceptual element, transnationalism has over a period of time been associated with transnational labour 
migration in relation to managing goods, work force and human movement between the country of origin and the host. Complexities and unforeseen experiences such as xenophobic attacks, human rights violations, labour exploitations, human trafficking and other related sociocultural problems cloud the realisation of the concept and practice of transnationalism. Public Administration scholars and practitioners cannot afford to ignore the aforementioned realities. Concerned with government behavior and process management in policymaking, intergovernment relations and cooperation, cross-border management, processing of asylum applications and process-management of matters relating to citizenship require sensitivity to transnational realities. Governments of the sub-Saharan countries should take in their strides the objective of establishing a common understanding of practice and management of crossborder transnational labour migration.

Mechanisms should be put in place in dealing with the aforementioned. In order to achieve success, democratic principles such as labour rights, open and transparent transaction handling between migrant workers and government officials, and institutions of the host countries, remains essential. Bilateral agreements on an international country-to-country scale should be encouraged. Growing trends such as the demise of the nation-state should not be discouraged since this should be perceived as the natural evolutionary nature of politics and human development. The new world order demands good management of transnational labour migration to achieve economic prosperity, political stability and balanced social agenda.

\section{References}

Adepoju, A. 2006. Perspectives on international migration and national development in SubSaharan Africa. Paper presented at the Expert Meeting on International Migration and National Development: Viewpoints and Policy Initiatives in the Country of Origin, Radboud University Nijmegen, 23-24 August 2006.

Auriacombe, C. 2007. Public governance and the public interest: Speaking truth to power. Professorial inaugural lecture at the University of Johannesburg, Auckland park Campus, Johannesburg, on 12 September 2007.

Brennan, E.M. 1996. Population, urbanization, environment and security. A survey of the issues by E.M. Brennan in Environmental change and Security Project Report of the Woodrow Wilson Center, Washington, http:www.si.edu [Accessed: 12 November 2015].

Briggs, L., McCormick, G. \& Way, J.T. 2008. Transnationalism: A category of analysis, American Quarterly, 60(3): 625-648.

Cano, G. 2005. The Mexico-North report on transnationalism. An article delivered at the $63^{\text {th }}$ Annual conference of the Midwest Political Science Association, Chicago, 7-10 April 2005.

Carruthers, J. 1995. The Kruger Park: A Social and Political History. Pinetown: University of Natal Press.

Castles, S. 2007. Twenty-first-century migration as a challenge to sociology. Journal of Ethnic Eo Migration Studies, 33(3): 351-371. 
Clapper, A.V. 2000. Organisational culture and transformation: The role of the Department of Public Service and Administration. Unpublished $\mathrm{PhD}$ thesis submitted to the Department of Public Administration and Management at the University of South Africa, Pretoria.

Clavin, P. 2005. Defining transnationalism. Contemporary European History, 14(4): 421-439. Cambridge: Cambridge University Press.

Department of Home Affairs, 2007. Legislation Administered by the National Department of Home Affairs. Pretoria: Government Printers.

Duri, F.P.T. 2010. Informal negotiation of the Zimbabwe - Mozambique border for survival by Mutare`s marginalized people. Journal of Developing Societies, 26(2): 125-163.

Gaidzanwa, R. 1999. Voting with their Feet: Migrant Zimbabwean Nurses and Doctors in the Era of Structural Adjustments. Uppsala: Nordic African Institute.

George, S. 2009. Globalisation and Transnationalism: Resource Notes. www.gooogle.com [Accessed: 19 March 2009].

Ley, D. 2004. Transnational spaces and everyday lives. Transactions of the Institute of British Geographers, 29: 151-164.

Manyange, D.N. 2014. Regional security governance within the East African Community: Prospects and challenges. African Peace and Conflict Journal, 7(2): 74-88.

Metropolis, 2007. Transnationalism and the meaning of citizenship in the $21^{\text {st }}$ century. Conversation Series, pp. 1-10. www.google.com [Accessed: 16 November 2015].

Martiniello, M. \& Rea, A. 2014. The concept of migratory careers: Elements for a new theoretical perspective of contemporary human mobility. Current Sociology, 62(7): 1079-1096.

Mazzucato, V. 2004. Transcending the nation: Explorations of transnationalism. In Kalb D., Pansters W. \& Siebers H. (eds.) Globalisation and Development: Themes and Concepts in Current Research. New York: Kluwer Academic Publishers.

Mulaudzi, C. 2009. New regionalism in southern Africa. Between South African hegemony and globalization. Lusotopie, XVI(1): 47-65.

Muzvidziwa, V.N. 2005. Women without Borders: Informal Cross-border Trade among Women in the Southern African Development Community. Addis Ababa: Organisation for Social Science Research in Eastern and Southern Africa.

Rodgers, G. 2009. The faint footprint of man: Representing race, place and conservation on the Mozambique-South Africa borderland. Journal of Refugee Studies, 22(3): 253-256.

Sirkeci, I. 2009. Transnational mobility and conflict. Migration Letters, 6(1): 3-14.

Solomon, H. 2003. Of Myths and Migration: Illegal Immigration into South Africa. Pretoria: University of South Africa.

Spaan, E. \& van Moppes, D. 2006. African Exodus? Trends and Patterns of International Migration in Sub-Sabaran Africa. Nijmegen, Netherlands: Radbound University.

Stiglitz, J. 2001. Foreword. In Polanyi, K. (ed.), The Great Transformation: The Political and Economic Origins of our Times. Boston: Beacon Press. 
Wikipedia, n.d. http://en.wikipedia.org/wiki/Transnationalism [Accessed: 19 March 2009].

Yawlui, R.M. 2013. The socio-economic impacts of xenophobia in South Africa: A case study of the Nelson Mandela Bay Metropole. Masters Dissertation submitted to the Department of Public Administration and Management at the Nelson Mandela Metropolitan University, Port Elizabeth.

Zondi, S. 2008. Xenophobic attacks: Towards an understanding of violence against Africa immigrants in South Africa. Africa Insight, 38(2): 26-35. 